\title{
Space nuclear power programme at risk
}

Washington. A joint US-Russian programme to develop a space-based nuclear reactor should either be enlarged to conduct fuelled tests at higher power levels or shut down, according to a report released last week by the US National Research Council (NRC).

The 30-year quest to develop space nuclear power is in danger of ending, says the panel, unless any of the three US federal agencies involved - the Department of Energy, National Aeronautics and Space Administration (NASA) or the Department of Defense - comes forward with a mission to justify continued research. And that, say most observers, is extremely unlikely.

The United States first flew a nuclear reactor in space in 1965 . But since then the research has suffered from uneven support. The 'Star Wars' anti-missile programme of the mid-1980s briefly revived interest, as did NASA's flirtation in the late 1980s with planning human missions to Mars. But by the early 1990s both programmes had been abandoned.

In 1991, the Defense Department acquired the first of several unfuelled Russian TOPAZ reactors, and began working with the Russians on a joint testing programme, which now costs $\$ 8.5$ million a year. But the TOPAZ international programme has been hamstrung by political constraints - the most important being that the project is prohibited from using live nuclear fuel. Instead, the reactor is heated electrically, limiting it to low power levels.

The NRC panel finds no fault with the work of the scientists on the TOPAZ programme, which is run by the Defense Nuclear Agency (recently renamed the Defense Special Weapons Agency). It simply says that, as a result of political constraints, the research is unlikely to produce good information on how nuclear power reactors would work in space.

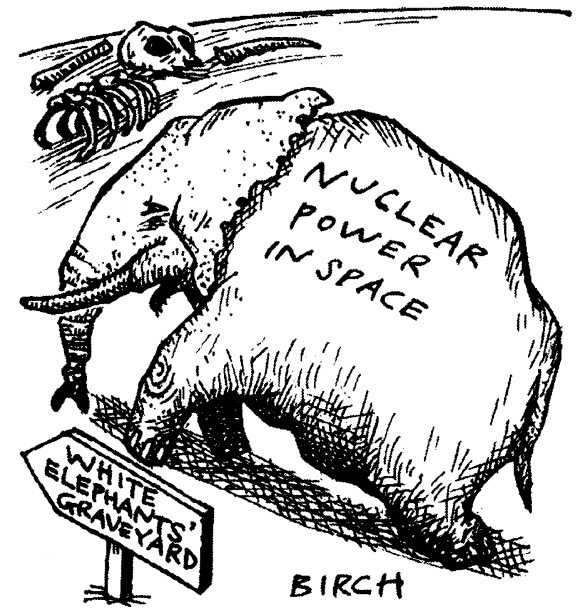

The panel was chaired by a retired US Air Force general, William Hoover, who once headed the Energy Department's nuclear weapons programme. The panel proposed an alternative to simply scrapping the research. By combining TOPAZ with advanced thermionic reactor research being sponsored by the Defense Department at $\$ 10$ million a year, allowing fuelled testing and lifting other constraints, the programme could provide real benefits.

But an even larger stumbling-block is that no agency has come forward with a solid mission for high-power nuclear reactors in space. Uses proposed in the past have included power sources for spacebased radars and lunar outposts.

Although NASA studies have concluded that human missions to Mars will need nuclear power, the agency is careful to avoid proposing any grandiose, budget-busting plans. Even the suggestion of using nuclear power in space has become politically charged. "[NASA] seems to be very skittish about anything nuclear," says Hoover. "There's a lot of ambivalence."

So, without support from other agencies, the programme is likely to die. If it does, says the NRC committee, an entire body of knowledge is likely to die with it.

Tony Reichhardt

\section{Budget hits 'political' research funded by tobacco tax}

San Francisco. Research considered to have a 'political' aim will not be eligible for support from state funds allocated to tobacco research under a rule adopted during California's budget negotiations last week.

The new budget allocation, which affects $\$ 60.4$ million in funding, also overrides the peer-review process and gives a state agency, under advice from a politically appointed committee, the final authority over grants.

The language has aroused the suspicions of tobacco-control advocates and scientists, who say that political pressure may harm funding of research projects critical of the tobacco industry and its supporters in the state legislature.

They say the budget language targets work by Stanton A. Glantz, professor of medicine at the University of California at San Francisco, who has drawn attention to legislators' ties to tobacco interests and to tobacco industry documents which reveal that industry lawyers have kept scientific knowledge of tobacco's deleterious effects hidden (see Nature 376, 205; 1995).

It would not be the first time Glantz's work has come under attack. Last autumn, the House of Representatives Appropriations Committee in the US Congress singled out Glantz's work as inappropriate for funding by the National Cancer Institute.
The allocation of the tobacco-research budget follows several years of bickering, in which state agencies fought over how to spend a tobacco tax of 25 cent per pack set aside by Californian voters in 1988 for tobacco-related education, research and health services.

Although the new language restores a large portion of the original funding that voters had directed toward research, a provision would prohibit use of the money for studies "of a partisan political nature", and submit the programme's expenditure plan to the state Department of Finance for review.

The department, in turn, would take advice from the Tobacco Education and Research Oversight Committee, a politically appointed panel which until now has only been generally responsible for the direction of the programme.

Jann Taber, a spokeswoman for the Assembly Speaker, Curt Pringle (Republican, Garden Grove), who inserted the language, said that Pringle's goal was to reinforce constitutional prohibitions against state funding of partisan political research. She claimed that the process of oversight would not change, with the oversight committee acting only in an advisory role. At the same time, however, Pringle's office condemned Glantz's work as inappropriate.
Glantz is reviewing tobacco industry activities in six states. His studies have indicated that state legislators who receive tobacco industry contributions are 42 times more likely to support the industry with their votes than others. According to Glantz's research, for example, Pringle has accepted $\$ 30,750$ of tobacco industry money during his legislative career. Under the new rule, the Department of Finance and the oversight committee would decide whether such research violated the rules on partisan political activities.

Mary Adam, of the California and Los Angeles affiliates of the American Heart Association, says that the policy sets a dangerous precedent by allowing a political body to tinker with research.

Larry Gruder, executive director of special research programmes in the office of the president of the University of California, says that the university, which manages the tobacco tax research funds for the state, would object to any attempt to target certain investigators or certain types of research.

Bowing to an outside committee or eliminating work such as Glantz's would violate the university's values and policies, he said. The 1996-97 California state budget is expected to be finalized and approved this week.

Sally Lehrman 